\title{
God undervisning og studenter som lykkes
}

En sammenligning av teoretiske og empiriske bidrag fra tre forskningsretninger

\section{Forfatterpresentasjon:}

Navn: Ida Katrine Riksaasen Hatlevik

Adresse: Sørliveien 10, 1482 Nittedal

Tlf: 98005256

E-post: $\underline{\text { i.k.r.hatlevik@ils.uio.no }}$

Stilling og arbeidssted: Postdoktor ved Institutt for lærerutdanning og skoleforskning, Universitetet i Oslo

\section{Sammendrag}

Hvordan studerer studenter som lykkes med sine studier? Hva kjennetegner god undervisning som fremmer hensiktsmessige måter å studere på? I artikkelen belyses disse spørsmålene ved å redegjøre for og å sammenligne bidrag fra de tre forskningsretningene Student engagement, Students' approaches to learning og Self-regulated learning. Til tross for mye overlapp gir hver av retningene særegne bidrag. I artikkelen argumenteres det for at man går glipp av viktig kunnskap om hva som påvirker og fremmer studenters læring, dersom man bare tar utgangspunkt $\mathrm{i}$ en eller to av retningene, og det skisseres praktiske implikasjoner og behov for videre studier.

\section{Innledning}

Studentenes innsats i eget læringsarbeid og kvaliteten på det undervisnings- og opplæringstilbudet som gis, er de to aspektene ved utdanningskvalitet som har størst innflytelse på studentenes faglige læringsutbytte av høyere utdanning (Gibbs, 2010, s. 5). Dette innebærer at kunnskap om hvilke undervisnings- og læringsformer og måter å studere på som gir god læring, er viktig både for studentene selv og for de som skal tilrettelegge for 
studentenes læring. Spørsmålene om hva som kjennetegner studenter som lykkes og hvilke undervisnings- og læringsformer som fremmer studentenes studieengasjement og læringsutbytte, er grundig behandlet innenfor de tre forskningsretningene Student engagement (studenters engasjement), Students' approaches to learning (studenters læringstilnærming) og Self-regulated learning (selvregulert læring) ${ }^{1}$. Selv om disse tre retningene har ulikt faglig utspring, og forskning innenfor hver av disse retningene $\mathrm{i}$ liten grad har henvist til bidrag fra hverandre ${ }^{2}$, har de kommet frem til lignende resultater når det gjelder hva som kjennetegner studenter som lykkes med sine studier, og hva som kjennetegner undervisning som fremmer studenters læring. Men til tross for likheter finnes det også forskjeller. Et viktig skille er om hovedfokus er på betydningen av læringskontekst eller på det lærende individ. Et hovedpoeng i denne artikkelen er at man vil miste særegne bidrag til kunnskap om studenters læring og hva som påvirker dette, dersom man velger å kun gjøre seg kjent med bidrag fra en av forskningsretningene.

Det finnes få studier som sammenligner de teoretiske og empiriske bidragene til hver av retningene. Denne artikkelen gir ikke en fullstendig fremstilling av all forskning som er gjort innenfor hver av retningene. Hensikten er å sammenligne hovedtrekk og bruke teoretiske og empiriske bidrag fra de tre retningene til å belyse følgende forskningsspørsmål:

1) Hva kjennetegner studenter som lykkes med sine studier?
A) Hvilke beskrivelser er overlappende for de tre retningene?
B) Hvilke beskrivelser er særegne for hver av retningene?

2) Hva kjennetegner god undervisning?
A) Hvilke beskrivelser er overlappende for de tre retningene?
B) Hvilke beskrivelser er særegne for hver av retningene?

Før jeg redegjør nærmere for hver av forskningsretningene og sammenligner deres bidrag, presenterer jeg i et eget metodeavsnitt valg av litteratur som brukes som grunnlag for 
redegjørelsen og sammenligningen. I redegjørelsen for hver forskningsretning gir jeg for hver retning en kort presentasjon av deres opprinnelse, faglige utspring og hovedtrekk ved retningens teoretiske og empiriske bidrag til å belyse hva som kjennetegner studenter som lykkes, og hva som kjennetegner god undervisning. I sammenligningen diskuterer jeg og gir i tabellform oversikt over likheter og forskjeller mellom retningenes beskrivelse av måter å studere på som det antas er av betydning for å lykkes med studiene og generelle prinsipper for god undervisning. I drøftingsdelen gir jeg en kritisk vurdering av hva de tre retningene bidrar med av teoretisk og empirisk kunnskap til å forstå studenters læring i ulike typer fag og utdanninger. I avslutningen oppsummerer jeg artikkelens bidrag, diskuterer hvilke praktiske implikasjoner denne kunnskapen om både kjennetegn ved studenter som lykkes og kjennetegn ved god undervisning, bør få for studenter, undervisere, programansvarlige og for utdanningsinstitusjoners arbeid med kvalitetsutvikling, samt skisserer behov for videre forskning.

\section{Metode}

I denne artikkelen er målet å belyse hva som kjennetegner studenter som lykkes med sine studier, og god undervisning ved å ta utgangspunkt i og sammenligne sentrale bidrag fra de tre forskningsretningene Student engagement, Students' approaches to learning og Selfregulated learning. Det er ikke innenfor rammen av denne artikkelen anledning til å gi en review av alt som er skrevet innenfor disse retningene. Med sentrale bidrag sikter jeg til faglitteratur i form av reviewstudier (Fredricks, Blumenfeld \& Paris, 2004; Kuh et al., 2014; McCormic, Kinzie \& Gonyea, 2013; Pascarella \& Terenzini, 2005; Sitzman \& Ely, 2011; Watkins, 2001) og fagbøker og artikler skrevet av forskere som har vært med på å utforme og legge det teoretiske og empiriske grunnlaget for retningene (Astin, 1984; Biggs, 1979; Entwistle, 2002; Furlong \& Christenson, 2008; Marton \& Säljö, 1976; Pace, 1980; Pintrich, 2000, 2003, 2004; Ramsden, 1991, 2003; Schunk, 2005; Tinto, 1994; Zimmerman, 2001). 
Når det gjelder identifisering av litteratur som sammenligner de teoretiske bidragene til hver av retningene, gjorde jeg søk i Eric og PsycINFO. Fra før kjente jeg til sammenligninger gjort av Heikkilä og Lonka (2006), Lonka, Olkinuora og Mäkinen (2004), Pintrich (2004) og Wolters og Taylor (2012). Dette er artikler/kapitler som sammenligner Self-regulated learning med en av de to andre retningene. Søket i PsycINFO ga meg kjennskap til en femte artikkel (Zusho, 2017) som sammenligner bidrag fra alle de tre retningene og skisserer en kompleks integrert modell over individ og kontekstrelaterte faktorer som påvirker studenters læring i klasserommet. Det som skiller min studie fra de fem andre sammenligningene, er at jeg ikke bare fokuserer på måter studenter kan studere på. I denne artikkelen har jeg et dobbelt fokus, både på hva som karakteriserer hensiktsmessige måter å studere på, og hva som kjennetegner undervisning som fremmer god læring hos studentene.

\section{Teoretisk og empirisk grunnlag: Redegjørelse for forskningsretningenes bidrag}

De tre forskningsretningene Student engagement, Students' approaches to learning og Selfregulated learning gir alle beskrivelser av måter studenter kan studere på. Imidlertid bruker retningene ulike betegnelser på disse måtene. De ulike betegnelsene reflekterer at de har unders $\varnothing \mathrm{kt}$ delvis overlappende, men ikke helt identiske fenomener, som engasjement $i$ egen læring og læringsmiljø, tilnarming til læring og selvregulering av egen læring. Når jeg ikke spesifikt viser til en av retningene, har jeg i denne artikkelen valgt å bruke måter studenter studerer på som en samlebetegnelse som er ment å være dekkende for alle de tre beskrivelsene. I tabell 1 gis en oversikt over sentrale begreper innenfor hver av retningene. 
Tabell 1. Oversikt over sentrale begreper innenfor hver forskningsretning.

\begin{tabular}{|c|c|c|}
\hline Student engagement & $\begin{array}{l}\text { Students' approaches to } \\
\text { learning }\end{array}$ & Self-regulated learning \\
\hline $\begin{array}{l}\text { Integrasjon og involvering: } \\
-\quad \text { faglig } \\
-\quad \text { sosialt } \\
\text { Engasjement: } \\
-\quad \text { akademisk } \\
-\quad \text { atferdsmessig } \\
-\quad \text { kognitivt } \\
-\quad \text { emosjonelt }\end{array}$ & $\begin{array}{l}\text { Overflatisk tilnærming } \\
\text { Dybdetilnærming } \\
\text { Strategisk tilnærming }\end{array}$ & $\begin{array}{l}\text { Selvregulering av kognisjon, } \\
\text { motivasjon, atferd og } \\
\text { læringskontekst gjennom: } \\
\text { - } \quad \text { planlegging } \\
\text { - } \quad \text { overvåking } \\
\text { - } \quad \text { kontroll } \\
\text { - } \quad \text { refleksjon }\end{array}$ \\
\hline
\end{tabular}

Tabell 1 viser at det innenfor hver av forskningsretningene opereres med ulike begreper som er sentrale i deres beskrivelse av studentenes måte å studere på. Selv om primærfokus i disse retningene har vært på måter studenter studerer på, er det innenfor alle de tre retningene forsket på sammenheng mellom måter å studere på og læringsutbytte, samt at det har blitt utledet generelle prinsipper for god undervisning. Nedenfor redegjør jeg først for hver av retningenes bidrag til å belyse hva som kjennetegner studenter som lykkes med sine studier, og hva som kjennetegner god undervisning. Deretter sammenligner jeg bidragene og drøfter hva som er felles, og hva hver tradisjon gir av særegne bidrag.

\section{Student engagement}

Student engagement er et paraplybegrep for beslektede ideer med røtter i amerikansk sosiologisk utdanningsforskning på hva som påvirker collegestudenters vurdering av utdanningstilbudet og deres akademiske prestasjoner (McCormick et al., 2013). Begrepet ble utviklet på slutten av 90-tallet som et resultat av en $\varnothing \mathrm{kt}$ interesse for prosessindikatorer. Denne interessen var forårsaket av en tiltagende frustrasjon over kvaliteten på college og universiteter (ibid). Begrepet Student engagement omfatter både individers atferd og oppfatninger samt kjennetegn ved læringstilbud og kontekst (ibid). Når det gjelder studenters atferd, har Student engagement-begrepet inkorporert i seg elementene tidsbruk (time on task), 
kvalitet på studentenes studieinnsats (quality of effort), involvering (involvement) og sosial og akademisk integrasjon (ibid). Sentrale forskningsbidrag som har vært med på å forme starten til denne retningen, er gitt av Pace (1980), Astin (1984) og Tinto (1994).

Pace (1980) fant at kvaliteten på studenters studieinnsats når det gjelder å nyttegjøre seg det opplæringstilbudet som institusjonen tilbyr, er en sentral forklaringsfaktor for læringsresultater. Astin (1984) postulerte i sin «student involvement theory» at studenters utbytte av utdanningen er proporsjonal med den fysiske og psykiske energi de investerer i sin utdanning. Tinto (1994) brukte mangel på sosial og akademisk integrasjon som forklaring på at studenter frivillig avslutter sin utdanning før den er fullført. Sosial integrasjon refererer til studenters opplevelse av interaksjon med medstudenter og ansatte og involvering $\mathrm{i}$ utenomfaglige aktiviteter. Akademisk integrasjon innebærer at studenter internaliserer akademiske normer, og at deres faglige prestasjoner tilfredsstiller eksplisitte akademiske krav som institusjonen stiller. Senere reviewstudier (Pascarella \& Terenzini, 2005; Kuh et al., 2014) bekrefter Pace og Astins bidrag.

Innenfor denne forskningsretningen fremheves det at studenters engasjement er et flerdimensjonalt fenomen, og kan deles inn i akademisk engasjement (academic engagement), atferdsmessig engasjement (behavioral engagement), kognitivt engasjement (cognitive engagement) og affektivt engasjement (affective engagement) (Furlong \& Christenson, 2008). Akademisk engasjement reflekterer tid brukt på studieaktiviteter, innleverte studiearbeider og oppnådde studiepoeng. Atferdsmessig engasjement handler om tilstedeværelse og aktiv deltagelse i undervisning og andre studierelaterte aktiviteter. Kognitivt engasjement handler om i hvilken grad studentene opplever innholdet i utdanningen som relevant for fremtidige mål. Det kommer til uttrykk gjennom interesse for læring, målsetting og selvregulerende atferd. Affektivt engasjement innebærer opplevelse av å høre til et studiemiljø og få støtte fra lærere, medstudenter og familie. Både akademisk og atferdsmessig engasjement er 
dimensjoner som er objektivt målbare. Imidlertid er det kognitivt og affektivt engasjement som forskning har vist at i størst grad er koblet til positivt læringsutbytte (Fredricks et al., 2004).

På bakgrunn av forskning på hvordan ulike lærings- og undervisningsformer påvirker studenters engasjement og læringsutbytte, har Chikering og Gamson (1987) formulerte syv prinsipper for god undervisningspraksis som er mye brukt:

- Oppmuntrer til kontakt mellom studenter og faglig ansatte

- Utvikler gjensidighet og samarbeid mellom studenter

- Oppmuntrer til aktiv læring

- Gir rask tilbakemelding til studenter på deres læringsarbeid og prestasjoner

- Vektlegger betydningen av tid brukt på studier

- Kommuniserer høye forventninger relatert til studenters innsats og prestasjon

- Respekterer at studenter har ulike talenter og foretrukne læringsstiler

Pascarella og Terenzinis (2005) reviewstudie støtter og ytterligere konkretiserer Chickering og Gamsons (1987) undervisningsprinsipper. De belyser særlig bruk av ulike studentaktive læringsformer i det regulære undervisningstilbudet som diskusjoner, notatskriving, samarbeidslæring (både lære sammen og lære av hverandre) og at studentene danner kollokviegrupper (Pascarella \& Terenzini, 2005, s. 101-114). I tillegg tar de opp at det er viktig å se i sammenheng og integrere på tvers av ulike emner og mellom det studentene skal lære ved utdanningsinstitusjonen og det som etterspørres i arbeidslivet (s. 647).

I forskning gjort innenfor Student engagement-retningen har oppmerksomheten i stor grad vært rettet mot målbare faktorer som tidsbruk og selvrapportert innsats og på betydningen av læringskonteksten i form av sosial og faglig integrasjon og involvering. De to andre forskningsretningene, som det redegjøres for nedenfor, er mer individorienterte og gir 
detaljerte beskrivelser av kognitive og motivasjonelle aspekter relatert til studenters måte å studere på.

\section{Students' approaches to learning}

Perspektivet Students' approaches to learning har dominert forskning på forholdet mellom hvordan studenter studerer og deres læringsutbytte i Europa og Australia (Lonka et al., 2004). Dette perspektivet springer ut av Marton og Säljös (1976) fenomenologiske studier av studenters mer eller mindre stabile læringstilnærminger og er senere utviklet gjennom multivariate analyser av spørreskjemadata (Biggs, 1979; Ramsden \& Entwistle, 1981).

Innenfor Students' approaches to learning-perspektivet er det identifisert tre tilnærminger; overflatisk (surface), dybde (deep) og strategisk (strategic), som studenter kan ha til sin egen læring, og som beskriver ulike måter å studere på (Biggs, 1979; Entwistle, McCune \& Walker, 2001; Marton \& Säljö, 1976; Ramsden, 2003). Studenter med en overflatisk tilnærming kjennetegnes av å gjøre minimalt med innsats for å møte studiekravene og av å konsentrere seg om å pugge og kunne det faglige innholdet de forventer å bli eksaminert i (ibid). Dette er en måte å studere på som innebærer at studenten ikke reflekterer over hensikten med læringsaktiviteten eller studiestrategien han eller hun bruker. Studenter med denne studietilnærmingen har problemer med både å forstå nye ideer og å se verdien av og mening med studiets innhold. Til kontrast kjennetegnes studenter med en dybdetilnærming av aktivt å engasjere seg og av å forstå det faglige innholdet. Studenter med en dybdetilnærming fokuserer på den overordnede meningen i innholdet, relaterer nye ideer til allerede tilegnet kunnskap og erfaringer, ser etter mønster og underliggende prinsipper, undersøker og argumenterer logisk og kritisk og er klar over at forståelsen utvikler seg underveis. Mens både dybde og overflatisk tilnærming beskriver hvordan studentene på ulikt vis engasjerer seg i innholdet i læringsoppgavene, handler strategisk tilnærming om hvordan studenter organiserer sin studering på (Ramsden, 2003, s. 43). Studenter med en strategisk 
tilnærming kjennetegnes av effektivt å styre tidsbruk og innsats, overvåke egen effektivitet og tilpasse innsats etter eksamineringskrav. Studenter med en strategisk tilnærming ønsker å oppnå gode karakterer og er villige til å legge ned mye innsats i studiene, men tilpasser læringstilnærmingen (overflatisk eller dybde) etter hva de oppfatter at vil gi best uttelling på eksamen (Entwistle et al., 2001; Ramsden, 2003). Entwistle (2002) avdekket at dybdetilnærming er knyttet til indre motivasjon, overflatisk tilnærming er knyttet til ytre motivasjon og/eller redsel for å mislykkes, og strategisk tilnærming er knyttet til behovet for å prestere godt.

I utgangspunktet var Marton og Säljös (1976) inndeling i dybde- og overflatisk tilnærming til læring en ren deskriptiv beskrivelse av ulike måter å studere på. Imidlertid har senere forskning avdekket at ulike tilnærmingene er koblet til ulikt læringsresultat (Entwistle et al., 2001; Ramsden, 2003; Watkins, 2001). Det læringsutbytte studentene får ved en overflatisk tilnærming, kjennetegnes av løsrevet kunnskap om enkeltmomenter, en begrenset forståelse av begreper, vanskeligheter med å gjenkjenne ideer som er nøkkelideer og problemer med å bruke kunnskapen i nye kontekster (Entwistle et al., 2001; Ramsden, 2003). Læringsutbytte fra dybdelæring, derimot, kjennetegnes av grundig kjennskap til hovedlinjene og det viktigste samt at kunnskapen er blitt ens egen. At kunnskapen er blitt ens egen, innebærer en evne til å bruke kunnskapen i nye situasjoner og til å generere ny mening og kunnskap (ibid). I en metastudie fant Watkins (2001) at dybdetilnærming og strategisk tilnærming er positivt korrelert med gode karakterer, mens en overflatisk tilnærming er negativt korrelert med gode karakterer.

Ramsden (1991) gjennomgikk en rekke tidligere studier og konkluderte med at ulikheter i kvaliteten på undervisningen er relatert til studenters læringsresultat. Watkins (2001) fant i sin metastudie at overflatisk læringstilnærming er assosiert med studenters opplevelse av for stor arbeidsmengde og ikke relevante vurderingsmetoder. Han fant også at 
både dybdetilnærming og en strategisk tilnærming er assosiert med god og støttende undervisning og med vektlegging av selvstendighet. På bakgrunn av hvordan ulike karakteristika ved undervisningskonteksten påvirker studentenes læringstilnærming og læringsutbytte, gir Ramsden (2003, s. 86-87) en liste over kjennetegn ved en god underviser:

- viser oppriktig interesse for fagkunnskapen

- gjør innholdet interessant og stimulerende

- tilpasser undervisningen etter studentenes faglige nivå

- forklarer innholdet enkelt

- gjør tydelig hva som må læres, hvorfor det må læres, og hvor godt det må læres

- viser studentene respekt og omsorg

- oppmuntrer studenter til å bli selvstendige

- improviserer og tilpasser undervisningen til nye krav

- bruker undervisningsmetoder og oppgaver som krever at studentene må lære innholdet grundig, samarbeide med medstudenter og ta ansvar for egen læring

- bruker eksamineringsmetoder som måler det en ønsker at studentene skal lære

- fokuserer på nøkkelbegreper og på å oppklare misforståelser i stedet for å skulle gå gjennom hele pensum

- gir best mulig tilbakemelding på studentarbeid

- $\quad$ søker å forbedre egen undervisning ved å lære av studenter og av forskning på utdanning

Students' approaches to learning-retningen beskriver ulike mer eller mindre stabile læringstilnærminger som studenter kan ha. Til sammenligning har forskningsretningene Student-engagement og Self-regulated learning et større fokus på kjennetegn ved den gruppen av studenter som lykkes. Self-regulated learning, som det redegjøres for nedenfor, har i tillegg 
et særlig fokus på hvordan studentene kan utvikle kognitive strategier (selvregulering) for å styre egen læringsprosess.

\section{Self-regulated learning}

Forskningsretningen Self-regulated learning oppsto i USA (Lonka et al., 2004) på midten av 80-tallet innenfor en psykologisk sosialkognitiv fagtradisjon (Zimmerman, 2001). Mens de to andre retningene i stor grad har utviklet sin teori på grunnlag av funn fra empiriske studier, er Self-regulated learning delvis teoridrevet (Pintrich, 2004). Forskning på selvregulering startet med undersøkelser av selvkontroll hos voksne og utvikling av selvkontroll hos barn. Den tidligste forskningen bar preg av å være terapeutisk ved at forskere lærte deltagere å endre dysfunksjonell atferd. I dag anvendes selvreguleringsprinsippene i forskning både på læring av akademiske, sosiale og motoriske ferdigheter (Schunk, 2005).

Metakognisjon, som handler om å være bevisst og reflektere over egen læringsprosess, er et sentralt begrep innenfor teori om selvregulering (Schunk, 2005). Teorien gir en grundig og konkret beskrivelse av hvordan selvregulerte studenter motiveres, og hvordan de regulerer egen læringsprosess (ibid). En typisk selvregulert lærende har innsikt i egen akademisk styrke og svakhet, har et repertoar av studiestrategier å velge blant, og velger å bruke den som passer best alt etter type læringsoppgave (Dweck, 2002). En selvregulert lærende forklarer både det å lykkes og det å mislykkes med faktorer som de selv kan kontrollere, som for eksempel studieinnsats (ibid). Videre har de en forståelse av at intelligens ikke er noe som er statisk, men noe som kan utvikles (Perry, Philips \& Hutchinson, 2006). Selvregulerte studenter har også en tendens til å tro at det å ta på seg utfordrende oppgaver, prøve ut det de har lært, utvikle en dypere forståelse av læringsinnholdet og gjøre en innsats, vil medføre gode karakterer (ibid).

Selvregulering kan deles inn i fire prosesser (Pintrich, 2004). Den første består i å planlegge og å sette seg mål for læringsaktiviteten. Den andre innebærer å overvåke egen 
motivasjon, forståelse og kompetanse for å mestre læringsoppgaven. Den tredje involverer kontroll av strategibruk og refleksjon over læringsarbeidet. Den fjerde handler om å reflektere over og komme med en reaksjon på resultatet, bl.a. evaluere egen innsats i forhold til hva man har lært. Forskning innenfor denne retningen viser at selvreguleringsprosessene er forbundet med kvalitativt god læring, høy grad av motivasjon og å lykkes både i utdanningen og senere i jobb (Pintrich, 2000). Av en metaanalyse fant Sitzman og Ely (2011) at de fleste selvreguleringsprosessene er moderat til sterkt korrelert med hverandre, noe som indikerer at de er innbyrdes forbundet. Videre fant de at de selvreguleringsprosessene som har sterkest effekt på læring, er egen målsetting for læringsarbeidet, utholdenhet, innsats og mestrings- og resultatforventning (self-efficacy).

Pintrich (2003) har utarbeidet prinsipper for god undervisning på bakgrunn av hva motivasjonsforskning har avdekket av faktorer som motiverer studentene, og dermed påvirker deres selvregulering og læring i klasserommet. Han påpeker nytten av å ta et multidisiplinært perspektiv og hevder at det ikke er én, men flere ulike faktorer som kan fungere motiverende i en læringskontekst.

Some students may be motivated and sustained through their self-efficacy beliefs, whereas others are motivated to try hard, persist, and achieve because of their goals, their personal interest and their value beliefs, or contextual factors that motivate, support and direct their behavior. (Pintrich 2003, s. 671.)

Studentenes motivasjon fremstår derfor som nøkkelen til å forstå studenters selvregulering av egen læring og dermed også til å forstå hvordan man kan legge til rette for studentenes læring i undervisningen. På bakgrunn av gjennomgangen av hva som motiverer studenter for læring, har Pintrich (2003, s. 672) formulert følgende prinsipper ${ }^{3}$ for god undervisning: 
- Utforme undervisning, læringsoppgaver og vurderingsformer slik at de fremmer mestring, læring, innsats og progresjon, og ikke fokuserer på at studentene sammenligner seg med hverandre.

- Variere undervisningen og vektlegge forståelse av innhold.

- Læringsoppgaver som er passe utfordrende, som utformes slik at studentene har mulighet til å mestre dem, og som oppleves som interessante og personlig meningsfulle for studentene.

- Studentene gis mulighet til å velge mellom ulike læringsoppgaver og utøve en viss grad av kontroll over læringsarbeidet.

- Tilbakemeldinger på studentarbeid som fokuserer på den enkeltes kompetanseutvikling (hvor de er i forhold til hvor de skal), og som tydelig viser studentene hva læringsarbeid innebærer selvkontroll, innsats og bruk av læringsstrategier.

- Læringsmiljøet er trygt og forutsigbart, og studentene oppmuntres til samarbeid og til å ta personlig og felles ansvar for læringsarbeidet.

- Engasjerte undervisere som viser interesse for læringsstoffet, og som tydeliggjør læringsinnholdets verdi, nytte og relevans.

Redegjørelsen for de tre forskningsretningene viser mange likhetstrekk. Imidlertid viser presentasjonen også at det er variasjon mellom retningene i begrepsbruk, fokus, detaljeringsgrad på beskrivelsene og hvilke forklaringer som fremheves. I neste avsnitt sammenlignes de ulike bidragene for å belyse hva som kjennetegner studenter som lykkes og god undervisning. 


\section{Sammenligning av bidragene til de tre forskningsretningene}

I dette avsnittet har jeg sammenstilt hovedbidragene til de tre retningene i tabell 2 og 3 . I

tabell 2 gis en oversikt over overlappende (jfr. forskningsspørsmål 1A) og særegne bidrag (jfr.

forskningsspørsmål 1B) til å beskrive og forklare hva som kjennetegner studenter som lykkes.

Tabell 2. Oversikt over overlappende og særegne bidrag fra de tre forskningsretningene for å beskrive kjennetegn ved og forklare årsaker til at studenter lykkes.

\begin{tabular}{|c|c|c|}
\hline & Studenter som lykkes, beskrivelser og forklaringer & Hovedfokus \\
\hline $\begin{array}{l}\text { Bidrag som er } \\
\text { overlappende for de tre } \\
\text { forskningsretningene }\end{array}$ & $\begin{array}{l}\text { Beskrivelser av aktive studenter som: } \\
\text { - tar ansvar for egen læring (agent i egen læring) } \\
\text { - har høy innsats og utholdenhet i læringsarbeidet } \\
\text { - er kognitivt engasjerte (velger hensiktsmessig studiestrategi } \\
\text { og overvåker egen innsats) }\end{array}$ & Individ \\
\hline $\begin{array}{l}\text { Bidrag som er } \\
\text { overlappende for } \\
\text { Students' approaches to } \\
\text { learning og Self- } \\
\text { regulated learning }\end{array}$ & $\begin{array}{l}\text { Forklaringer som vektlegger: } \\
\text { - motivasjonens betydning for studentenes måte å studere på }\end{array}$ & Individ \\
\hline $\begin{array}{l}\text { Saregent bidrag fra } \\
\text { Student engagement }\end{array}$ & $\begin{array}{l}\text { Detaljert beskrivelse av som vektlegger betydningen av: } \\
\text { - faglig og sosial integrasjon og involvering med medstudenter } \\
\text { og faglig ansatte } \\
\text { - sosial bakgrunn } \\
\text { - tidsbruk }\end{array}$ & Kontekst \\
\hline $\begin{array}{l}\text { Saregent bidrag fra } \\
\text { Students' approaches to } \\
\text { learning }\end{array}$ & $\begin{array}{l}\text { Detaljert beskrivelse av ulike læringstilnærminger (overflatisk, } \\
\text { dybde og strategisk) }\end{array}$ & Individ \\
\hline $\begin{array}{l}\text { Særegent bidrag fra } \\
\text { Self-regulated learning }\end{array}$ & $\begin{array}{l}\text { Detaljert beskrivelse av selvreguleringsprosessen (planlegging, } \\
\text { overvåking, kontroll og refleksjon knyttet til kognisjon, } \\
\text { motivasjon, atferd og læringskontekst) }\end{array}$ & Individ \\
\hline
\end{tabular}

Tabell 2 viser at i alle de tre retningene kan «idealstudentene» beskrives som aktive og engasjerte i eget læringsarbeid. De gjør en stor egeninnsats, er utholdende, bruker energi på å gå i dybden av fagstoffet og søker å forstå læringsinnholdet. Beskrivelsen av selvregulerte studenter har mye til felles med det som i Student engagement-retningen beskrives som kognitivt engasjerte studenter, og som i Students' approaches to learning-retningen beskrives som kombinasjonen av å ha en strategisk- og dybdetilnærming til læring. Både strategisk tilnærming, kognitivt engasjement og selvregulering innebærer å være bevisst, overvåke og styre egen læringsprosess og velge måter å studere på som er hensiktsmessige $\mathrm{i}$ forhold til hva som oppfattes som målet med læringen. I likhet med det å ha en dybdetilnærming søker kognitivt engasjerte og selvregulert studenter forståelse og å maksimere egen læring. Mens 
Students' approaches to learning-retningen søker å identifisere ulike forholdsvis stabile læringstilnærminger, har retningene Student engagement og Self-regulated learning i større grad fokusert på spesifikke kjennetegn ved den måten å studere på som fremstilles som et ideal. Studenter som ligger tett opp til dette idealet, forventes å lykkes med studier i høyere utdanning.

I Student engagement-retningen er det både et fokus på individ og kontekst i beskrivelsen av kjennetegn ved studenter som lykkes, mens beskrivelsene i Students' approaches to learning og Self-regulated learning hovedsakelig handler om hva det enkelte lærende individ gjør. Innenfor Student engagement-retningen fremheves i større grad enn innenfor de to andre retningene at studentenes engasjement ikke bare handler om kognitivt og affektivt engasjement, men at det også handler om at de er godt integrert i studiefelleskapet med både medstudenter og faglærere. Dette er ikke i motsetning til hva de andre retningene tar opp. Det å søke å bli godt integrert i studiefellesskapet er noe som studenter med en strategisk læringstilnærming og studenter som er selvregulerte, gjør dersom de tror det vil føre til bedre læring. Men i forskning på Students’approaches to learning og Self-regulated learning er ikke involvering og integrasjon i læringsmiljøet et like sentralt element som trekkes frem når en skal beskrive kjennetegn ved studenter som lykkes.

I alle tre retningene legges det vekt på at studenter er agenter i egen læring, og at de kan påvirke sin egen læringssituasjon og sitt eget læringsutbytte. Imidlertid er det innenfor Self-regulated learning-retningen at det legges mest vekt på studenter som agenter i egen læring (Wolters \& Taylor, 2012). I denne retningen gis detaljerte beskrivelser av hvordan studenter kan overvåke, regulere og kontrollere kognitive, motivasjonsmessige, følelsesmessige og atferdsmessige aspekter ved egen læring og noen aspekter ved den konteksten læringen foregår i (Pintrich, 2004). I stedet for at læring er noe som hender som et 
resultat av deltagelse i undervisning, er læring ifølge teorien om selvregulert læring en aktivitet som den lærende gjør for sin egen skyld (Zimmerman, 2001).

Det er også forskjell på hvor langt de enkelte forskningsretningene går i å undersøke og forklare mekanismer som ligger bak det å lykkes med studier (Wolters \& Taylor, 2012; Pintrich, 2004), og dermed også forskjell på begrunnelser for de forskjellige retningenes undervisningsprinsipper. Motivasjon som underliggende forklaringsvariabel er mer fremtredende i forskning innenfor Students' approaches to learning og Self-regulated learning enn hva som er tilfellet innenfor Student engagement. Self-regulated learning gir den grundigste beskrivelsen av kompleksiteten i studenters motivasjon og måte å studere på (ibid). Det er også innenfor Self-regulated learning at det fokuseres mest på betydningen av motivasjon som drivkraft for studenters engasjement i læringen, hvordan den kan kontrolleres og reguleres av den lærende, og hvordan en i undervisningen kan fremme motivasjon for engasjement og selvregulering (ibid).

Representanter innenfor alle de tre retningene har utledet generelle prinsipper for god undervisning. Prinsippene har stor grad av overlapp (forskningsspørsmål 2A), men de har også enkelte særtrekk (forskningsspørsmål 2B) som avspeiler om retningen har fokus på individ eller kontekst. I tabell 3 gis en oversikt over overlappende og særegne bidrag til å beskrive generelle prinsipper for god undervisning. 


\section{Generelle prinsipper for god undervisning}

Bidrag som er overlappende Kommunisere tydelige mål for læringsarbeidet (hva som skal læres)

for de tre

forskningsretningene

(Chikering \& Gamson, 1987; læres)

Pascarella \& Terenzini, 2005; Skape et trygt læringsmiljø

Pintrich, 2003; Ramsden, 2003)

Ha engasjerte undervisere

Tydeliggjøre hva som kreves av studentene (hvordan få til å lære)

Tydeliggjøre læringsinnholdets verdi, nytte og relevans (hvorfor noe skal

Bruke undervisningsformer og læringsoppgaver som fremmer

studentaktivitet og samarbeid mellom studenter

Variere undervisningsformer

Tilpasse undervisningen etter studentenes forutsetninger

Gi gode tilbakemeldinger til studentene på deres arbeid

Bidrag som er overlappende Gjøre innholdet interessant

for Students' approaches to Vektlegge forståelse

learning og Self-regulated

Oppmuntre studentene til å bli selvstendige og ta ansvar for egen læring

learning (Pintrich, 2003;

Ramsden, 2003)

\section{Særegent bidrag fra}

Student engagement

(Chikering \& Gamson, 1987;

Pascarella \& Terenzini, 2005)

\section{Særegent bidrag fra}

Students' approaches to learning

(Ramsden, 2003)

\begin{tabular}{|l} 
\\
\hline Særegent bidrag fra Self- \\
regulated learning
\end{tabular}

(Pintrich, 2003)
Tilrettelegge for god kontakt mellom studenter og mellom studenter og faglig ansatte

Integrere på tvers av ulike emner

Fokusere på nøkkelbegreper og det viktigste fremfor å dekke hele pensum

Forklare innholdet enkelt

Oppklare misforståelser

Bruke eksamineringsmetoder som måler det man ønsker at studentene skal lære

Søke å forbedre egen undervisning

Bruke undervisnings-, lærings- og vurderingsformer som fremmer

opplevelse av mestring, læring, innsats og progresjon og ikke fokuserer på at studenter sammenligner seg med hverandre

Utforme læringsoppgaver som oppleves som interessante og personlig meningsfulle for studentene

Gi studentene mulighet til å velge mellom ulike læringsoppgaver og utøve en viss grad av kontroll over læringsarbeidet

Klargjøre for studentene hva selvregulering innebærer 
Av tabell 3 går det frem at $i$ alle retningene fremheves det at god undervisning forutsetter at det kommuniseres tydelige mål for hva som skal læres, hvor godt det skal læres, og begrunnelser for hvorfor det må læres. Videre er det viktig at læringsmiljøet oppleves som trygt slik at studentene tør være aktive, og at underviserne er engasjert i det faglige innholdet de underviser i. I tillegg fremheves variasjon i undervisningen, studentaktive læringsformer, tilrettelegging for samarbeid mellom studentene og gode tilbakemeldinger til studentene på deres arbeid.

Innenfor alle retningene påpekes sammenheng mellom undervisningstilbud, studentenes måte å studere på og deres læringsutbytte. Imidlertid retter Student engagementretningen i større grad enn de andre oppmerksomheten mot hvordan læringskonteksten spiller inn og påvirker studentenes læring, og hva en i undervisningen kan gjøre for å fremme studentenes sosiale og faglige involvering og integrasjon. Det er også innenfor denne retningen hvor det eksplisitt påpekes betydningen av integrering på tvers av emner (Pascarella \& Terenzini, 2005). Integrering på tvers av emner kan for eksempel handle om å forklare for studentene hvordan ulike typer innhold, kunnskapselementer fra ulike fagtradisjoner og ulike læringsaktiviteter står i forhold til hverandre.

I alle retningene pekes det på at studenter som lykkes, kjennetegnes av at de jobber godt med stoffet og får en grundig forståelse av det som skal læres. Imidlertid er det innenfor Students' approaches to learning at det eksplisitt er formulert undervisningsprinsipper som særlig vektlegger betydningen av å gjøre læringsinnholdet forståelig for studentene, å bruke undervisningen til å oppklare misforståelser og formidle det viktigste i læringsinnholdet. Innenfor denne retningen pekes det også på at strategiske studenter konsentrerer sin studieinnsats på det de tror de blir eksaminert i, og at det derfor er viktig i eksamineringen å søke å måle det man ønsker at studentene skal lære (Ramsden, 2003). 
Forskning gjort innenfor alle de tre retningene påpeker hvor viktig det er at studieinnholdet oppleves interessant og relevant for studentene, altså at utdanningsinnholdet oppleves som verdifullt og meningsfullt for dem (Wolters \& Taylor, 2012; Ramsden, 2003). Innenfor Self-regulated learning har Pintrich (2003) formulert relevans som et eget kjennetegn på god undervisning og bruker expectancy value-theory (Wigfield \& Eccles, 2000) for å forklare hvorfor det er viktig at studentene opplever læringsinnholdet og undervisningen som relevant, nyttig og meningsfullt. Pintrich (2003) utleder alle sine undervisningsprinsipper fra motivasjonsteori. Han gir dermed en teoretisk forklaring på hvordan hvert kjennetegn på god undervisning kan fremme studentenes motivasjon for engasjement og aktiv deltakelse i undervisning og læring. Hovedfokuset i Self-regulated learning er på hva det lærende individet selv kan gjøre for å få mest mulig læring ut av det utdanningstilbudet som gis, og hvordan det selv kan styre og regulere egen læringsprosess. Et viktig særegent bidrag som denne retningen gir, er kunnskap om hvordan man i undervisningen kan motivere studentene og lære studentene å bli selvregulerte og være proaktive i egen læring, altså til selv å mestre, ta kontroll over og ta ansvar for egen læringsprosess og derigjennom påvirke sitt utbytte av utdanningen.

\section{Drøfting}

I tabell 2 og 3 presenteres lister over overlappende og særegne bidrag for hver av de tre retningene til å belyse hva som kjennetegner studenter som lykkes, og hva som kjennetegner god undervisning. Sammenligningen viser at Student engagement bidrar særlig med å få frem betydningen av læringskonteksten, og at studentene er faglig og sosialt involvert og integrert med medstudenter og med de faglig ansatte. Students’ approach to learning har et særlig fokus på dybdelæring og studentenes forståelse. Self-regulated learning gir den mest detaljerte beskrivelsen av hva som kjennetegner studenter som lykkes. Den gir et særlig bidrag til å forstå hvordan studenter kan være agenter i egen læring, gjennom selv å regulere egen 
læringsprosess og egen motivasjon for læringsarbeidet. I tillegg bidrar denne retningen med kunnskap om hvordan man i undervisningen kan fremme studenters studiemotivasjon og selvregulering. En ulempe knyttet til veldig detaljerte beskrivelser av et fenomen, slik som i Self-regulated learning, er at de kan være vanskeligere å forstå og anvende. Fordelen med Student engagement og Students' approaches to learnings beskrivelser er at de er forholdsvis lettfattelige, også for de som ikke har studenters læring som forskningsfelt. Faren er imidlertid at beskrivelsene blir for generelle og ikke fanger opp sentrale aspekter ved og bakenforliggende årsaker til fenomenet man ønsker å få kunnskap om.

I alle de tre retningene er det utledet til dels overlappende prinsipper for god undervisning som er tiltenkt å bidra til at studentene lykkes og får et godt læringsutbytte gjennom å fremme hensiktsmessige måter å studere på. Det er gjort korrelasjonsstudier som bekrefter disse forventede sammenhengene mellom undervisningstilbud, måten studentene studerer på og deres læringsutbytte (se for eksempel Watkins, 2001; Diseth 2007a og b; Ning \& Downing, 2010). Men det er få longitudinelle studier som ser på hvordan opplevelse av undervisningstilbud målt på ett tidspunkt påvirker senere studieengasjement og faglig utbytte på et noe senere tidspunkt, og omvendt. Dette innebærer at det er noe uklart om betydningen av kvaliteten på undervisningstilbud for studentenes læringsutbytte fullstendig medieres gjennom studentenes måte å studere på, eller om undervisningstilbud kan ha en selvstendig effekt på studentenes læringsutbytte.

Forskningen innenfor alle de tre retningene har i stor grad fokusert på undervisning og studenters erfaringer i disiplinorienterte studieprogrammer innenfor høyere utdanning. Denne forskningen har i liten grad undersøkt om det er særtrekk ved utdanningene som er av betydning for studentenes motivasjon, engasjement og måte å studere på. Den får heller ikke frem hvordan fagspesifikke særtrekk ved utdanningene eller ulike former for kunnskap og kompetanse som skal læres, er av betydning for hensiktsmessig utforming og valg av 
læringsoppgaver og opplærings- og undervisningsformer. For eksempel vil akademiske fag med store krav til innlæring av faktakunnskap ha andre utfordringer enn fag med stort innslag av refleksjons- og danningskomponenter. Tilsvarende vil ferdighetslæring innebære andre utfordringer enn akademisk kunnskapslæring. Til tross for disse svakhetene viser forskning på studenters læring i profesjonsutdanninger at mange av de generelle prinsippene for god undervisning som de tre retningene har identifisert (se tabell 3), også gjelder for studenters praksisopplæring. Billett og Choy (2013) understreker nettopp betydningen av studentenes eget engasjement, innsats og det å være proaktiv i egen læring og oppsøke gode læringssituasjoner i praksisopplæringen. I tillegg viser en gjennomgang av forskning på studenters læring i praksisperioder i ulike profesjonsutdanninger at det er viktig med et trygt læringsmiljø, og at studentene selv får være aktive og prøve seg i en autentisk arbeidskontekst (Hatlevik, 2014). Videre viser slik forskning at det er viktig med kompetente og engasjerte praksisveiledere som er gode rollemodeller, og som gir gode tilbakemeldinger på studentenes eget læringsarbeid i praksis og knytter praksiserfaringer til teoretisk kunnskap (ibid). Imidlertid finnes det få studier som eksplisitt har undersøkt om kvaliteten på utdanningsinstitusjonenes undervisning har samme betydning for studieengasjement og læringsutbytte i profesjonsutdanninger som i disiplinorienterte studieprogrammer, eller om for eksempel praksiserfaringer er av større betydning.

\section{Avslutning: oppsummering, praktiske implikasjoner og behov for videre studier}

I denne artikkelen har jeg løftet frem at til tross for store overlapp gir de tre forskningsretningene Student engagement, Students' approaches to learning og Self-regulated learning særegne bidrag til å belyse kjennetegn ved studenter som lykkes med sine studier og kjennetegn ved god undervisning. En viktig forskjell mellom retningene er om hovedfokus er rettet mot konteksten eller mot individet. For å forstå og legge til rette for studenters læring er det viktig å ta hensyn til både individ og kontekst og hvordan kjennetegn ved dem begge 
spiller sammen og påvirker studentenes læringsprosess. Jeg vil konkludere med at man går glipp av viktig kunnskap om hva som påvirker studentenes mulighet til å lykkes med sine studier, dersom man velger å ta utgangspunkt i kun en av forskningsretningene. Videre vil jeg fremheve at det er behov for longitudinelle studier av sammenhenger mellom undervisningstilbud, studentenes måte å studere på og deres læringsutbytte innenfor ulike utdanningsprogrammer, både innenfor programmer som har all sin undervisning ved utdanningsinstitusjonen, og programmer hvor deler av opplæringen foregår i praksisfeltet knyttet til eksterne virksomheter.

På bakgrunn av gjennomgangen av bidragene til å belyse hva som kjennetegner studenter som lykkes og god undervisning, vil jeg trekke frem to praktiske implikasjoner. Det første handler om at studenter bør gjøres kjent med hva som kreves for å lykkes med sine studier. En del studenter er allerede selvregulerte og har stort studieengasjement, mens andre trenger hjelp til å lære hva selvregulering innebærer, og den betydningen dette har for deres egen læring. De generelle prinsippene for god undervisning kan hjelpe et stykke på vei i tilretteleggingen for studentenes læring. Imidlertid kan det være en utfordring å få studenter til å ta til seg kunnskap om hensiktsmessige måter å studere på. Særlig gjelder dette studenter som ikke selv ser at de har behov for metakunnskap om hvordan de skal studere. Det er derfor behov for systematisert kunnskap om hvordan man kan få den sistnevnte studentgruppen til å se relevansen av kunnskap om betydningen av engasjement og sosial og faglig involvering $\mathrm{i}$ studiemiljøet og selvregulering av egen læring.

Den andre praktiske implikasjonen handler om utvikling av undervisningskvalitet. Utvikling av god undervisning forutsetter at det fra institusjonelt hold gis incentiver som motiverer undervisningspersonalet til å bruke tid og krefter på å videreutvikle egen undervisningspraksis. Det forutsetter også at det settes av tid og legges vekt på å utvikle gode rutiner for kollegaveiledning og bruk av studenttilbakemeldinger til den enkelte underviser. I 
hvilken grad de nevnte generelle kjennetegnene ved god undervisning (se tabell 3) er til stede, gir indikasjoner på om undervisningskvaliteten kan karakteriseres som god. Kjennetegnene på god undervisning kan altså brukes som «ideal» ved planlegging og videreutvikling av undervisningstilbud. Imidlertid er det behov for oversiktsstudier av hvordan utvikling av undervisningskvalitet foregår ved ulike utdanningsinstitusjoner. Dette handler om hvilke rutiner og incentiver som gis ved ulike institusjoner for å motivere undervisningspersonalet til å bruke tid til å videreutvikle egen undervisningspraksis.

\section{Referanser}

Astin, Alexander W. (1984). Student involvement: A developmental theory for higher education. Journal of college student personnel, 25(4), 297-308.

Biggs, John (1979). Individual differences in study processes and the quality of learning outcomes. Higher education, 8(4), 381-394. doi: 10.1007/BF01680526.

Billett, Stephen, \& Choy, Sarojni (2013). Learning through work: emerging perspectives and new challenges. Journal of Workplace Learning, 25(4), 264-276. doi: $10.1108 / 13665621311316447$.

Chickering, Arthur W., \& Gamson, Zelda F. (1987). Seven principles for good practice in undergraduate education. AAHE Bulletin, March 1987, 3-7.

Christenson, Sandra L, Reschly, Amy L., \& Wylie, Cathy (red.) (2012). Handbook of research on student engagement. London: Springer. doi: 10.1007/978-1-4614-2018-7.

Diseth, Åge (2007a). Students' evaluation of teaching, approaches to learning, and academic achievement. Scandinavian Journal of Educational Research, 51(2), 185-204. doi: 10.1080/00313830701191654.

Diseth, Åge (2007b). Approaches to learning, course experience and examination grade among undergraduate psychology students: Testing of mediator effects and construct validity. Studies in Higher Education, 32(3), 373-388. doi: 10.1080/03075070701346949.

Diseth, Åge (2011). Self-efficacy, goal orientations and learning strategies as mediators between preceding and subsequent academic achievement. Learning and Individual 
Differences, 21(2), 191-195. doi: 10.1016/j.lindif.2011.01.003.

Dweck, Carol S. (2002). Messages that motivate: How praise molds students' beliefs, motivation, and performance (in surprising ways). I Joshua Aronson (red.). Improving academic achievement: Impact of psychological factors on education (s. 37-60). San Diego: Academic Press. doi: 10.1016/b978-012064455-1/50006-3.

Entwistle, Noel (2002). Understanding Academic Performance at University: A Research Retrospective. I Charles Desforges \& Richard Fox (red.). Teaching and Learning. The Essential Readings in Developmental Psychology (s. 108-124). Oxford: Blackwell Publishers Ltd. doi: 10.1002/9780470690048.ch5.

Entwistle, Noel, McCune, Velda, \& Walker, Paul (2001). Conceptions, Styles and Approaches Within Higher Education: Analytic Abstractions and Everyday Experience. I Robert J. Sternberg \& Lee-Fang Zhang (red.). Perspectives on Thinking, Learning and Cognitive Styles (s. 103-136). Mahwah. NJ: Lawrence Erlbaum Associates. doi: 10.4324/9781410605986.

Entwistle, Noel, \& Peterson, Elizabeth R. (2004). Conceptions of learning and knowledge in higher education: Relationships with study behaviour and influences of learning environments. International Journal of Educational Research, 41(6), 407-428. doi: 10.1016/j.ijer.2005.08.009.

Fredricks, Jennifer A., Blumenfeld, Phyllis C., \& Paris, Alison H. (2004). School Engagement: Potential of the Concept, State of the Evidence. Review of Educational Research. 74(1), 59-109. doi: 10.3102/00346543074001059.

Furlong, Michael J., \& Christenson, Sandra L. (2008). Engaging students at school and with learning: A relevant construct for all students. Psychology in the Schools, 45(5), 365368. doi: 10.1002/pits.20302.

Gibbs, Graham (2010). Dimensions of Quality. York: The Higher education Academy. http://www.celt.mmu.ac.uk/policy/ltmmu/docs/Dimensions_of_Quality\%20\%20Graha m\%20Gibbs.pdf.

Hatlevik, Ida K. R. (2014). Meningsfulle sammenhenger. En studie av sammenhenger mellom laring på ulike arenaer og utvikling av ulike aspekter ved profesjonell kompetanse hos studenter i sykepleier-, larer- og sosialarbeiderutdanningen. Høgskolen i Oslo og Akershus. Avhandling $2014 \mathrm{nr} 4$. 
Heikkilä, Annamari, \& Lonka, Kirsti (2006). Studying in higher education: students' approaches to learning, self-regulation, and cognitive strategies. Studies in Higher Education. 31(1), 99-117. doi: 10.1080/03075070500392433.

Kuh, George D., Kinzie, Jillian, Buckley, Jennifer A., Bridges, Brian K., \& Hayek, John C. (2014). Piecing together the student success puzzle. Hoboken, NJ: John Wiley.

Lonka, Kirsti, Olkinuora, Erkki, \& Mäkinen, Jarkko (2004). Aspects and prospects of measuring studying and learning in higher education. Educational Psychology Review, 16(4), 301-323. doi: 10.1007/s10648-004-0002-1.

Marton, Ference, \& Säljö, Roger (1976). On Qualitative Differences in Learning: I—Outcome and process. British journal of educational psychology, 46(1), 4-11. doi: 10.1111/j.2044-8279.1976.tb02980.x.

McCormick, Alexander C., Kinzie, Jillian, \& Gonyea, Robert M. (2013). Student engagement: Bridging research and practice to improve the quality of undergraduate education. I M. B. Paulsen (red.). Higher education: Handbook of theory and research (s. 47-92). Dordrecht: Springer. doi: 10.1007/978-94-007-5836-0_2.

Ning, Hoi K., \& Downing, Kevin (2010). Connections between learning experience, study behaviour and academic performance: a longitudinal study. Educational Research, 52(4), 457-468. doi: 10.1080/00131881.2010.524754.

Pace, Robert (1980). Measuring the quality of student effort. Current Issues in Higher Education, 2(1), 10-16.

Pascarella, Ernest T., \& Terenzini, Patrick T. (2005). How College Affects Students. Volume 2. A Third Decade of Research. San Francisco: Jossey-Bass.

Perry, Nancy E., Phillips, Lynda, \& Hutchinson, Lynda (2006). Mentoring Student Teachers to Support Self-Regulated Learning. The Elementary School Journal, 106(3), $237-$ 254. doi: $10.1086 / 501485$.

Pintrich, Paul R. (2000). Multiple goals and multiple pathways: The role of goal orientation in learning and achievement. Journal of Educational Psychology, 92, 544-555. doi: 10.1037/0022-0663.92.3.544.

Pintrich, Paul. R. (2003). A motivational science perspective on the role of student motivation in learning and teaching contexts. Journal of educational Psychology, 95(4), 667-686. doi: 10.1037/0022-0663.95.4.667. 
Pintrich, Paul R. (2004). A conceptual framework for assessing motivation and self-regulated learning in college students. Educational psychology review, 16(4), 385-407. doi: 10.1007/s10648-004-0006-x.

Ramsden, Paul (1991). A performance indicator for teaching quality in higher education: The Course Experience Questionnaire. Studies in Higher Education, 16, 129-150. doi: 10.1080/03075079112331382944.

Ramsden, Paul (2003). Learning to teach in higher education (2 ed.). London: RoutledgeFalmer. doi: 10.4324/9780203507711.

Ramsden, Paul, \& Entwistle, Noel J. (1981). Effects of Academic Departments on Students' Approaches to Studying. British Journal of Educational Psychology, 51(3), 368-383. doi: Authors: 10.1111/j.2044-8279.1981.tb02493.x.

Schunk, Dale H. (2005). Self-Regulated Learning: The Educational Legacy of Paul R. Pintrich. Educational Psychologist, 40(2), 85-94. doi: 10.1207/s15326985ep4002_3.

Sitzman, Traci, \& Ely, Katherine (2011). A Meta-Analysis of Self-Regulated Learning in Work-Related Training and Educational Attainment: What We Know and Where We Need to Go. Psychological Bulletin. 137(3), 421-442. doi: 10.1037/a0022777.

Tinto, Vincent (1994). Leaving college: Rethinking the causes and cures of student attrition. Chicago: University of Chicago Press. doi: 10.7208/chicago/9780226922461.001.0001.

Vermunt, Jan D., \& Vermetten, Yvonne J. (2004). Patterns in Student Learning: Relationships Between Learning Strategies, Conceptions of Learning, and Learning Orientations. Educational Psychology Review, 16(4), 359-384. doi: 10.1007/s10648-004-0005-y.

Watkins, David (2001). Correlates of approaches to learning: A cross-cultural meta-analysis. I Robert J. Sternberg \& Lee-Fang Zhang (red.). Perspectives on Thinking, Learning and Cognitive Styles (s. 165-195). London: Lawrence Erlbaum Associates Publishers. doi: $10.4324 / 9781410605986$.

Wigfield, Allan, \& Eccles, Jacquelynne S. (2000). Expectancy-value theory of achievement motivation. Contemporary Educational Psychology, 25(1), 68-81. doi: 10.1006/ceps.1999.1015.

Wolters, Christopher A., \& Taylor, Daniel J. (2012). A self-regulated Learning Perspective on Student Engagement. I Sandra L. Christenson, Amy L. Reshly \& Cathy Wylie (red.). 
Handbook on Student Engagement. London: Springer. doi: 10.1007/978-1-4614-20187_30.

Zimmerman, Barry J. (2001). Theories of self-regulated learning and academic achievement:

An overview and analysis. I Barry J. Zimmerman \& Dale H. Schunk (red.). Selfregulated learning and academic achievement. Theoretical perspectives. (2 ed., s. 1 37). London: Lawrence Erlbaum Associates. doi: 10.4324/9781410601032.

Zusho, Akane (2017). Toward an integrated model of student learning in the college classroom. Educational Psychology Review, 2(29), 301-324. doi: 10.1007/s10648017-9408-4.

\section{Noter}

\footnotetext{
1 Jeg velger å bruke de engelske termene videre i artikkelen når jeg refererer til forskningsretningene.

${ }^{2}$ I den senere tid er gjort studier som kombinerer enkelte elementer fra ulike forskningsretninger (se for eksempel Diseth, 2011; Vermunt \& Vermetten, 2004).

${ }^{3}$ Prinsippene til Pintrich er presentert etter hvordan de imøtekommer ulike motivasjonsteorier. Det er derfor en del overlapp mellom flere av de ulike prinsippene han har utformet. Jeg har derfor valgt å omformulere og slå noen av dem sammen.
} 